\title{
Pola Permukiman Prasejarah: Kajian Atas Data Hasil Penelitian Megalitik di Pakauman, Bondowoso
}

\section{Diman Suryanto}

Keywords: pattern, model, settlement, megalithic, spatial, area, distribution

\section{How to Cite:}

Suryanto, D. (2002). Pola Permukiman Prasejarah: Kajian Atas Data Hasil Penelitian Megalitik di Pakauman, Bondowoso. Berkala Arkeologi, 22(1), 8-21. https://doi.org/10.30883/jba.v22i1.846

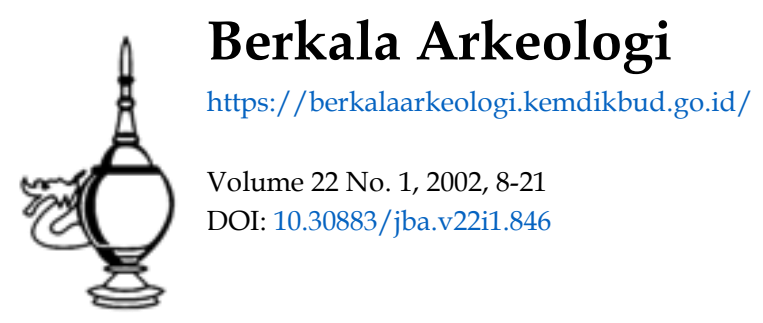

\section{c) (7) (2)}

This work is licensed under a Creative Commons Attribution-NonCommercial-ShareAlike 4.0 International License. 


\title{
POLA PERMUKIMAN PRASEJARAH: \\ Kajian Atas Data Hasil Penelitian Megalitik di Pakauman, Bondowoso
}

\author{
Diman Suryanto \\ (Balai Arkeologi Yogyakarta)
}

\section{A. Pendahuluan}

\section{Latar Belakang}

Berdasarkan fungsi dan aktivitasnya situs-situs arkeologi dapat dibedakan menjadi beberapa tipe, antara lain situs-situs : perdagangan, pasar, perbengkelan, penguburan, pemujaan, dan permukiman. Situs-situs tersebut menggambarkan adanya hubungan yang erat antara lokasi situs dengan strategi manusia dalam memenuhi kebutuhannya. Dengan demikian lokasi situs dapat mempengaruhi tipe situs. Tipe situs ditandai oleh sisa-sisa kegiatan manusia yang ditinggalkan. Situs permukiman atau situs habitasi misalnya, merupakan situs tempat manusia bertempat tinggal dan beraktivitas seharihari. Sisa aktivitas sehari-hari dapat diamati, antara lain sisa penggunaan api (adanya arang, abu), sisa sampah, bekas perlengkapan dapur dan perlengkapan rumah tangga lainnya, jaringan atau bekas jalan, sisa bangunan rumah atau tempat tinggal, bekas pemujaan, lokasi penguburan, dan bekas perbengkelan.

Mengenai 'pola permukiman arkeologi' kiranya dapat diajukan definisi Parsons, yaitu bahwa pola permukiman arkeologi adalah cara yang dilakukan oleh manusia di dalam mengatur dirinya di muka bumi dimana dia hidup. Pengertian ini dapat menunjukkan tempat tinggalnya, susunan bangunan, sifat dan watak bangunan, serta aspek-aspek kehidupan lainnya. Pola-pola permukiman dapat merupakan refleksi dari alam lingkungan, tingkatan teknologi dan bermacam-macam institusi yang berlaku dalam suatu komunitas guna mengatur alam tersebut (Parsons, 1972). Dengan pengertian seperti ini, kiranya dapat diketahui hubungan antara pola suatu permukiman arkeologi dengan aspek-aspek kebudayaan, serta berkaitan erat dengan gejala-gejala geografis atau lingkungan alamnya.

Hubungan antara manusia dengan lingkungan masa lalu sudah lama mendapat perhatian dan sudah lama pula dipelajari oleh ahli arkeologi. Oleh karena itu banyak prinsip-prinsip umum ekologi yang digunakan dalam berbagai penelitian arkeologi (Hardesty 1980; Kirch 1980). Kajian mengenai manusia dengan lingkungannya semacam ini antara lain berkaitan dengan studi permukiman arkeologi. Kondisi variabel yang berbeda menyebabkan timbulnya bermacam-macam pola permukiman. Pola permukiman merupakan perwujudan dari cara manusia mengatur di dalam lingkungannya di muka bumi. 
Masalahnya adalah bagaimana cara kita memperoleh pengetahuan tentang adanya hubungan antar manusia dan lingkungan tersebut, dan hubungan macam apa yang telah terjadi pada masa itu. Permasalahan yang penting untuk dikaji ialah cara pemanfaatan sumberdaya lingkungan untuk memenuhi kebutuhan manusia, baik yang berkenaan dengan perolehan makanan dan perlindungan diri, maupun penempatan dirinya di muka bumi, meliputi penempatan bangunan untuk tempat beraktivitas.

Kajian ini bertujuan untuk mencoba mengembangkan penelitian permukiman prasejarah, khususnya untuk skala meso (yang berkaitan dengan situs), serta dilaksanakan dengan strategi dan metode yang sesuai dengan hakekat studi arkeologi ruang di Indonesia. Arkeologi-ruang merupakan salah satu studi khusus dalam bidang arkeologi, yang pada pokoknya lebih menitik-beratkan perhatian pada pengkajian dimensi ruang (spatial) dari pada dimensi bentuk (formal) dan dimensi waktu (temporal) dari benda dan situs. Bahkan arkeologi ruang tidak hanya mengkaji hubungan lokasional atau keruangan antar benda (artefak) dan situs, tetapi juga mengkaji hubungan antara bentuk-bentuk data arkeologi lain yang kesemuanya itu disebut sebagai unsur-unsur (elements) yang terdiri dari struktur, situs dan lingkungan fisik yang dimanfaatkan sebagai sumberdaya (Clarke 1977).

Kajian permukiman ini didasarkan atas hasil penelitian di situs Pakauman, Desa Pakauman, Kecamatan Grujugan, Kabupaten Bondowoso, Provinsi Jawa Timur, pada tahun 1985 yang lalu. Kajian ini menjadi amat penting karena di situs Pakauman yang mengandung banyak tinggalan megalitik itu, kini telah berdiri sebuah pabrik pengolahan kayu..

\section{Permasalah dan Hipotesis}

Telah disebut pada bagian depan, bahwa pola permukiman adalah cara manusia mengatur dirinya dimuka bumi dimana ia hidup, Pengertian demikian dapat menunjukkan tempat tinggal, susunan bangunan, dan berbagai sisa aktivitas manusia. Atau dengan kata lain, pola permukiman arkeologi merupakan refleksi alam sekitar, tingkatan teknologi dan aspek-aspek kehidupan lainnya.

Pada masa perundagian di Pakauman, aspek-aspek kehidupan dapat diamati pada tinggalan megalitik yang monumental yang dibuat dari bahan tahan lama yaitu batu. Berdasarkan fungsinya tinggalam megalitik di Pakauman dapat dibedakan menjadi 3 kelompok. Pertama, kelompok batu kenong merupakan sisa bangunan (umpak) dengan fungsi sebagai penyangga bangunan rumah. Kedua, kelompok dolmen dan sarkofagus berfungsi sebagai wadah atau tempat kubur/mayat. Ketiga, kelompok menhir, arca menhir dan kursi batu berfungsi sebagai media pemujaan arwah nenek moyang. Ketiga kelompok temuan tersebut memiliki jenis, distribusi, serta fungsi 
yang berbeda, memberi petunjuk jelas kepada kita tentang adanya pola permukiman arkeologi prasejarah, khususnya dari masa perundagian di Jawa Timur.

Berdasarkan atas hal-hal tersebut di atas, masalah dalam kajian ini dapat diajukan, Pertama, bagaimana bentuk dan pola permukiman prasejarah di Pakauman, Bondowoso. Kedua, melalui berbagai jenis tinggalan megalitik yang ada, bagaimana aspek-aspek kehidupan atau aktivitas manusia dapat dijelaskan.

Berkaitan dengan masalah tersebut kiranya dapat disimpulkan sementara (sebagai hipotesis) bahwa pola permukiman di Pakauman terbentuk sesuai dengan gagasan, konsep, pikiran yang ada pada masyarakat megalitik saat itu (sistem budaya). Kemudian gagasan, konsep, dan pikiran ini mendorong adanya perilaku atau berbagai aktivitas yang terjadi (sistem sosial), dan pada akhirnya aktivitas tersebut meninggalkan berbagai bentuk tinggalan arkeologi (budaya materi) yang dapat kita saksikan dilokasi penelitian.

Penempatan lokasi permukiman, didasarkan atas potensi lahan dan keberadaan air, serta faktor lingkungan lainnya. Atau secara singkat penempatan lokasi permukiman agar dapat menunjang terlaksananya aktivitas manusia dalam permukiman, terutama tentang hal-hal yang berhubungan dengan bertahan hidup (makanan, musuh, menyenangkan dan menakutkan).

Bentuk permukiman di Pakauman, dapat dikatakan benbentuk kecil (semacam pedukuhan). Permukiman tesebut dibangun dekat Sungai Sampeyan yang mengalir dilembah antara Pegunungan Hiyang di sebelah barat, dan dataran tinggi Ijen di sebelah timur.Sungai Sampeyan bermuara di selat Madura.

Di dalam permukiman terdapat sekurang-kurangnya 26 buah bangunan rumah tinggalm, dan 1 buah bangunan diantaranya merupakan bangunan publik yang berukuran lebih besar dari rumah lainnya. Masyarakatnya telah mengenal kehidupan religi dengan sentral pemujaan leluhur. Media pemujaan yang ditinggalkan berupa menhir, pelinggih dan arca menhir. Di samping pemujaan leluhur, masyarakat telah mengenal sistem penguburan, yang menggunakan dolmen dan sarkofagus. Di sampimg itu dapat ditetahui pula bahwa masyarakat mempunyai mata pencaharian bercocok tanam, di samping telah memiliki ketrampilan tehnik membuat gerabah, mengecor besi dan kerajinan dengan kulit kayu.

\section{Kerangka Teori}

Arkeologi permukiman dapat didefinisikan sebagai bagian dari disiplin arkeologi yang memusatkan perhatian pada persebaran okupasi (penghunian) dan kegiatan manusia, dengan tujuan memahami sistem teknologi, sitem sosial, dan sitem religi dari 
masyarakat masa lalu (Mundardjito 1990). Dari definisi tersebut terdapat 3 ciri pokok permukiman yaitu (1) persebaran, (2) hubungan-hubungan, dan (3) satuan ruang.

Persebaran tinggalan arkeologi merupakan petunjuk atau bukti okupasi manusia, beserta kegiatan-kegiatan yang berkaitan dengan tinggalan arkeologi tersebut. Hal itu dapat diasumsikan sebagai perwujudan dari gagasan dan tindakan manusia masa lalu. Atau dengan kata lain untuk memahami gagasan dan tindakan manusia masa lalu, kita dapat menggunakan data persebaran tinggalan arkeologi di muka bumi, selain itu pola sebaran dari bukti-bukti kegiatan manusia tersebut dapat menjadi sumber data bagi pola pikir dan pola tindaknya.

Sebagaimana dikemukakan di atas, tulisan ini berusaha mengkaji sejumlah tinggalan megalitik di Pakauman, terutama berupa sebaran dan hubungan antara berbagai jenis tinggalan megalitik. Ini berarti bahwa pengkajian ini tidak melihat tinggalan megalitik sebagai satu entitas (entity) yang berdiri sendiri, tetapi memandang semua tingalan megalitik di Pakauman secara keseluruhan. Tinggalan tersebut tidak dikaji misalnya dari segi bentuk dan ukuran (untuk menjawab pertanyaan apa dan bagaimana ukurannya) tetapi dari segi keletakannya pada bentang lahan (untuk menjawab pertanyaan dimana lokasinya dan bagaimana sebaran dan fungsinya)

Sebaran tinggalan megalitik di Pakauman polanya dapat diamati langsung secara empirik (observed pattern), dalam kajian ini dapat dianggap sebagai satu produk yang terwujud sejak masa perundagian di Jawa Timur. Pola sebaran tinggalan megalitik ini diduga merupakan wujud nyata dari pola gagasan dan pola perilaku masyarakat megalitik mengenai penempatan, pengaturan dan penyebaran berbagai jenis tinggalan megalitik di Pakauman.

Berbagai jenis tinggalan megalitik memiliki fungsi yang berbeda-beda seperti (kelompok) batu kenong berfungsi sebagai umpak bangunan, dolmen dan sarkofagus berfungsi sebagai tempat kubur, dan arca menhir dan menhir erat hubungannya dengan pemujaan leluhur.

Pemolaan keruangan dari berbagai jenis tinggalan megalitik tersebut dapat mencerminkan pemolaan aktivitas manusia masa lalu (Schiffer 1972). Di samping itu dalam tingkat operasionalnya, kajian permukiman berskala meso ini menggunakan satu pendekatan determinan ekologi (ecological determinants approach) (Thomas 1979) yang pada pokoknya memusatkan perhatian pada analisis keragaman pola sebaran.

Pendekatan determinan ekologi ini, memandang bahwa sekumpulan faktor lingkungan yang khas dalam suatu daerah mengkondisikan penempatan situs arkeologi dan jenis tinggalan arkeologi. Pendekatan ini memandang bahwa permukiman manusia masa 
lalu seringkali ditempatkan pada suatu bentang alam tertentu (yang khas), sebagai upaya penyesuaian dengan lingkungannya (proses adaptasi). Dengan pendekatan ekologi semacam ini, maka pola sebaran tinggalan megalitik di Pakauman dapat dianggap berkaitan dengan pola pemanfaatan sumberdaya lingkungan masa lalu, dan pola ini mungkin berorientasi pada konsep minimisasi energi dan maksimisasi hasil kerja (Clarke 1977). Dengan kata lain sebaran tinggalan megalitik di suatu lokasi berkorelasi erat dengan sumberdaya alam dan lingkungan yang bervariasi, serta menghasilkan pola hubungan di antara jenis tinggalan megalitik yang bervariasi pula. Dengan demikian tinggalan arkeologi yang berkorelasi dengan sumberdaya alam, diduga tidak akan menampakkan pola acak (Hodder, 1977).

\section{Metode dan Teknik Penelitian}

Suatu metode penelitian, tidak lain hanya merupakan alat atau cara untuk mencapai tujuan. Oleh karena itu perlu diketahui lebih dahulu apa tujuan studi permukiman ini. Sudah barang tentu tujuan studi permukiman berakar pada tujuan umum ilmu arkeologi, yaitu: (1) merekonstruksi sejarah kebudayaan, (2) merekonstruksi cara-cara hidup masyarakat masa lalu, (3) penggambaran proses budaya (Binford, 1984). Berdasarkan tujuan umum tersebut, maka dapat diketahui bahwa tujuan studi permukiman berkait dengan tujuan umum ke dua yaitu rekonstruksi cara-cara hidup masyarakat masa lalu.

Setelah diketahui tujuan studi permukiman, selanjutnya dapat dipilih metode penelitian permukiman. Metode penelitian permukiman pada hakekatnya sama dengan metode penelitian arkeologi pada umumnya. Dalam metode dan teknik penelitian permukiman diberikan penekanan perolehan data mengenai indikator adanya pola pemukiman.

Metode penelitian pada umumnya terdiri dari 3 tingkatan: (1)Tingkat pengumpulan data, yaitu pengumpulan data dengan metode penjajakan, survei, dan ekskavasi. (2) Tingkat pengolahan data yaitu dengan metode analisis khusus dan analisis kontekstual (pendekatan ekologi/ ecological approach) (3) Tingkat interpretasi data yaitu berusaha menafsirkan data dengan metode-metode sintesis, dan metode analogi historis dan etnografis.

\section{B. Hasil-Hasil Penelitian}

Data material yang dipakai sebagai landasan kajian adalah hasil survei dan ekskavasi di situs Pakauman Bondowoso tahun 1985. Data tersebut terdiri dari 2 jenis yaitu (1) sebaran tinggalan megalitik, dan (2) hasil-hasil ekskvasi. Kedua jenis data tersebut dijelaskan dibawah ini. . 


\section{Sebaran Tinggalan Megalitik}

Survei permukaan tanah di situs Pakauman, desa Pakauman, Kecamatan Grujugan, Kabupaten Bondowoso, Provinsi Jawa Timur, menghasilkan peta sebaran tinggalan megalitik. Berdasarkan fungsinya jenis-jenis tinggalan megalitik di Pakauman dapat dikelompokkan mejadi : (1) batu kenong (berfungsi sebagai umpak bangunan), (2) dolmen dan sarkofagus (berfungsi sebagai makam) dan (3) arca menhir, menhir dan kursi batu (berfungsi sebagai pemujaan).

\section{(a) Batu Kenong}

Batu kenong merupakan istilah penduduk setempat, bentuknya silindrik dengan tonjolan di puncaknya. Keberadaan batu kenong di Pakauman selalu berkelompok, kelompok yang terkecil berjumlah 3 buah batu kenong, dan kelompok terbesar terdiri 20 buah batu kenong. Dalam situs ditemukan 26 kelompok batu kenong.

Salah satu kelompok batu kenong di Pakauman telah digali oleh Willems pada tahun 1938 dan menemukan: pecahan gerabah, periuk, manik-manik kaca, sebuah gelang besi, dan 5 buah pemukul kulit kayu (Soejono 1984). Kelompok batu kenong di Pakauman sejak penelitian tersebut sampai sekarang belum diketahui fungsinya.

Untuk mengetahui fungsi tersebut, kiranya dapat dilakukan dengan analogi historis, yaitu membandingkan dengan fungsi batu kenong dari masa yang lebih kemudian (masa Klasik) misalnya kelompok batu batu kenong atau umpak di Sentonorejo atau Lebak Jabung di daerah Trowulan Mojokerto. Fungsi batu kenong pada masa Klasik ini sudah cukup jelas yaitu sebagai umpak bangunan, dengan demikian fungsi batu kenong di Pakauman dapat diduga sebagai umpak bangunan pula. Dengan demikian kelompok-kelompok batu kenong di Pakauman (tercatat 26 kelompok) adalah merupakan sisa-sisa bangunan rumah.

Batu kenong sebagai umpak, merupakan unsur bangunan bagian bawah atau pondasi. Bahan bangunan lainnya (bagian atas) berupa kayu atau bambu dan atapnya dari daun-daun atau jenis rumput-rumputan, yang tidak tahan lama sehingga tidak ditemukan sisa-sisanya. Penggambaran bentuk rumah dengan bahan bangunan seperti tersebut di atas tidaklah mudah. Salah satu acuannya adalah bentuk rumah pada tingkat permulaan di Indonesia (analogi etnografi). Bentuk rumah tersebut berukuran kecil, berbentuk kebulat-bulatan, dengan atap yang dibuat dari daun-daun, dan atap tersebut langsung menempel ke tanah. Bentuk seperti ini diduga merupakan bentuk yang paling tua di Indonesia dan sampai sekarang masih dapat dijumpai di Timor dan Kalimantan Barat (Soejono, 1984). 
Berdasarkan pengamatan sederhana sekurang-kurangnya terdapat 2 tipe bangunan rumah, yaitu bangunan individual dan bangunan publik.Kelompok batu kenong yang jumlahnya 20 buah dapat diduga sebagai bangunan publik karena memiliki 20 umpak dan dengan demikian berukuran relatif besar.

\section{(b) Dolmen. dan sarkofagus}

Tinggalan megalitik jenis dolmen, oleh penduduk setempat disebut "pandhusa" atau "makam cina". Dolmen adalah jenis batu kubur yang biasanya mengarah timur-barat, terdiri atas lantai dari papan batu, beberapa batu tegak sebagai dinding dan ditutup oleh sebuah batu besar. Di bagian timur kadang-kadang juga di bagian barat terdapat semacam pintu masuk. Penelitian terhadap dolmen telah banyak dilakukan, antara lain oleh Steinmetz (1898), Hubenet (1903). B. de Haan (1921), dan Willems (1940).

Ekskavasi Willems tahun 1940 membuktikan bahwa dolmen benar-benar berfungsi sebagai kuburan. Dalam kubur terdapat tulang-tulang manusia, sisa bekal kubur seperti pecahan periuk, sebuah pecahan keramik Cina (dari abad 9) dan pahat besi. Dolmen lainnya yang pernah digali oleh de Haan menghasilkan temuan gigi manusia, manik-manik sebanyak 79 buah dalam berbagi ukuran dan terbuat dari batu, kaca, dan terakota. Temuan lainnya adalah 1 buah cincin emas (Soejono 1984).

Berbeda dengan dolmen atau "pandhusa", sarkofagus adalah tempat kubur, terdiri wadah dan tutup, bentuk dan ukurannya sama (simitris). Dinding muka sarkofagus kadang-kadang dihias dengan ukiran bermotif binatang berkaki empat, burung dan bentuk manusia. Balai Arkeologi Yogyakarta dalam penelitiannya tahun 1985 menemukan 71 buah dolmen dan 21 buah sarkofagus. Kedua jenis bangunan megalitik ini ditemukan dalam satu situs dan berfungsi sebagai wadah kubur.

\section{(c) Arca menhir, menhir, dan kursi batu}

Arca menhir ditemukan 1 buah tergeletak di bawah pematang di dekat lokasi penggalian Willems dan dapat diduga erat hubungannya dengan pemujaan leluhur. Arca ini berukuran tinggi $160 \mathrm{~cm}$, berbentuk kepala besar, masif, tanpa pahatan wajah. Pahatan kaki tidak ada, bentuk bagian bawah meruncing untuk menancapkan ke dalam tanah (Soejono 1984).

Menhir atau batu tegak, adalah sebuah batu panjang yang didirikan tegak sebagai batu peringatan dalam hubungannya dengan pemujaan arwah leluhur. Selama penelitian di Pakauman menemukan 2 buah menhir.

Kursi batu yang juga disebut pelinggih adalah batu dengan permukaan datar, kadangkadang di belakangnya berdiri batu lain sehingga menyerupai bentuk kursi. Di duga 
fungsinya sebagai tempat duduk para arwah leluhur. Ketiga jenis tinggalan ini (arca menhir, menhir, dan kursi batu) masuk dalam kelompok tinggalan yang berfungsi sebagai media pemujaan kepada roh leluhur.

\section{Diskripsi Lingkungan}

Situs Pakauman adalah sebidang tanah tegalan dan sekaligus merupakan lahan pertanian. Lokasi tersebut berbatasan di sebelah utara dukuh Tasnan desa Taman, di sebelah barat desa Dawuhan, di sebelah selatan dukuh Pakauman dan dukuh Pedaringan di desa Krajan Pakauman. Batas paling timur adalah sungai Sampeyan yang mengalir ke arah utara dan bermuara di selat Madura.

Sungai Sampeyan berada di lembah antara Pegunungan Hiyang di sebelah barat dan Dataran Tinggi Ijen di sebelah timur. Situs Pakauman berada pada ketingggian 333 meter di atas permukaan laut. Topografi daerah Pakauman termasuk datar sampai berombak, dengan relief sekitar 1meter. Kelerengannya sebesar sebesar 1-2 derajat dengan arah dominan ke timur.

Vegetasi di sekitar situs adalah pohon jati dan pohon sono (di sebelah barat), dan pohon pinus di sebelah timur laut. Jenis tumbuhan lainnya adalah pohon kelapa, pisang, bambu, dan tanaman budidaya lainnya.

Berdasarkan kondisi lingkungan tersebut terdapat kecenderungan bahwa permukiman di Pakauman (sebagai tempat beraktivitas) memilih tempat yang elevasinya relatif rendah dengan jenis tanaman yang bervariasi. Dengan demikian sumberdaya lingkungan yang dijadikan dasar penentuan lokasi permukiman adalah: tersedianya lahan pertanian, sumberdaya alam (hutan jati, sono dan pinus), dekat sungai atau sumber air. Sungai Sampeyan di samping merupakan sumber air, terdapat kandungan batu yang merupakan bahan baku pembuatan monumen megalitik.

\section{Ekskavasi}

Tujuan ekskavasi adalah untuk mencari data pendukung dari dalam tanah khususnya berupa unsur-unsur permukiman. Pemilihan sektor penggalian dilakukan dengan memilih suatu kelompok batu kenong atas dasar pertimbangan tertentu, misalnya susunan batu kenongnya masih lengkap (insitu) dalam ukuran yang berbeda, misalnya ukuran besar, sedang dan kecil. Hal ini dimaksudkan agar perolehan data dari dalam tanah cukup beragam dan pada gilirannya akan diketahui apakah ukuran kelompok batu kenong menunjukkan fungsi yang berbeda.

Ekskavasi terhadap batu kenong di Pakauman telah berlangsung 2 tahap, yaitu tahap I dilaksanakan bulan April 1985 dan tahap II pada Desember 1985. Ekskavasi tahap I 
dapat menyelesaikan 3 sektor atau 13 kotak penggalian dan 1 buah kotak Lubang Uji. Ekskavasi tahap II dapat menyelesaikan 2 sektor atau 8 kotak penggalian.

Hasil-hasil ekskavasi adalah pecahan gerabah polos dan berhias, (masing-masing terdiri dari pecahan bagian bibir, leher, badan, dan dasar), periuk, manik-manik, gelang besi, dan alat pemukul kulit kayu,fragmen besi dan potongan emas. Temuan yang membuktikan adanya aktivitas penguburan seperti tercermin pada hasil ekskavasi dolmen oleh Willems dan de Haan (Soejono, 1984). Hasil ekskavasi itu adalah berupa tulang manusia dan sisa bekal kubur berupa pecahan periuk, keramik asing dan pahat besi, gigi manusia dan manik-manik.

Hasil-hasil ekskavasi tersebut di atas secara keseluruhan mencerminkan adanya aktivitas masyarakat dan adanya pola permukiman.

\section{Pola Permukiman di Pakauman}

Seperti telah disebut di bagian depan, pola permukiman arkeologi di sini mengikuti definisi Parsons, yaitu bahwa pola permukiman arkeologi adalah cara yang dilakukan oleh manusia di dalam mengatur dirinya di muka bumi dimana dia hidup. Pola permukiman dapat merupakan refleksi dari alam lingkungan, tingkatan teknologi, dan bermacam-macam institusi yang berlaku dalam suatu komunitas guna mengatur alam tersebut (Parsons, 1972).

Pengertian ini dapat menunjukkan tempat tinggal atau lokasinya, susunan, sifat dan watak bangunan, serta aspek-aspek kehidupan lainnya. Dengan pengertian seperti ini, kiranya dapat dijelaskan unsur-unsur mengenai pola permukiman seperti: pemilihan lokasi permukiman, bentuk desa dan pola perkampungan, mata pencaharian hidup, kehidupan religi dan aspek-spek kebudayaan lainnya.

\section{Pemilihan Lokasi Permukiman}

Hubungan antara situs dengan variabel lingkungan, mengacu pada pertimbangan lingkungan apa saja yang menjadi landasan untuk penentuan penempatan situs. Situs Pakauman mempunyai ketinggian 333 meter di atas permukaan air laut. Di samping itu dengan pengamatan sederhana terhadap permukaan tanah, dapat diperoleh gambaran relatif bahwa permukaan tanah di lokasi situs mempunyai kelerengan relatif datar sampai landai.

Berdasarkan data emperik tersebut, kiranya dapat ditafsirkan bahwa daerah yang datar dan landai merupakan tempat-tempat yang banyak dimanfaatkan manusia pada masa itu untuk penempatan perumahan sebagai pusat kegiatan. Pada lokasi semacam ini 
keleluasaan orang untuk bergerak mudah diperoleh dibanding dengan daerah yang miring, agak curam, dan curam. Disamping itu pada daerah yang datar dan landai air permukaan akan mengalir lebih lambat tanpa menimbulkan erosi humus, sehingga kesuburan tanah terjamin.

Hubungan antara sungai dengan permukiman merupakan hal penting pula untuk dikaji. Situs Pakauman merupakan Daerah Aliran Sungai (DAS) Sungai Sampean, situs yang berukuran panjang 2.000 meter arah timur-barat, dan lebar 1.500 meter arah utara-selatan, disebelah timur berbatasan langsung dengan Sungai Sampean tersebut. Data lingkungan ini dapat ditafsirkan bahwa sungai pada masa itu mampu mencukupi kebutuhan air sebagai kebutuhan dasar manusia untuk kehidupan sehari-hari. Di samping itu Sungai Sampean mengandung banyak bongkahan batu yang dapat dimanfaatkan sebagai bahan pembuatan bangunan megalitik.

\section{Bentuk Desa dan Pola Perkampungan}

Desa atau perkampungan di Pakauman terdiri dari 26 buah rumah yang berdiri di atas umpak batu. Susunan umpak berbentuk persegi panjang, bujur sangkar dan bentuk kebulat-bulatan. Konstruksi bangunan bagian atas dari bahan kayu atau bambu dan atapnya dari daun-daun. Bahan bangunan rumah yang dari kayu atau bambu, dan daun-daun termasuk bahan yang tidak tahan lama dan mudah rusak sehingga tidak ditemukan sisa-sisanya. Tidak tahannya bahan bangunan di daerah tropik yang berhawa lembab adalah hal yang umum, seperti terjadi di hutan tropik di Amerika Selatan seperti yang diungkapkan oleh B.J. Meggers dan Clifford Evans Jr (Soejono,1984). Satu-satunya bahan bangunan yang tahan lama adalah batu, berupa umpak bangunan (sebelumnya disebut batu kenong).

Untuk menggambarkan kembali bangunan rumah tempat tinggal pada masa prasejarah amatlah sukar. Sesuai dengan data empirik, kemungkinan bangunan rumah dari masa perundagian di Pakauman merupakan bentuk yang paling awal di Indonesia. Ukuran rumah kecil dan hanya untuk anggota keluarga kecil. Bentuk atapnya langsung menyentuh tanah. Bentuk seperti ini diduga merupakan bentuk yang paling tua di Indonesia dan sampai sekarang masih dapat dijumpai di Timor dan Kalimantan Barat (Soejono,R.P. 1984).

Berdasarkan pengamatan sederhana, keletakan bangunan-bangunan rumah tinggal tersebut berpola mengelompok yaitu berada di tengah-tengah situs. Rumah-rumah sebagian besar tersusun ditepi jalan, meskipun ada juga yang terpencil. Di tengah permukiman terdapat 1 buah bangunan berbentuk empat persegi panjang dengan pertemuan umum atau bangunan publik. 
Di samping susunan kenong yang ternyata merupakan umpak bangunan, di situs Pakauman terdapat jenis tinggalan lain yaitu dolmen, sarkofagus, arca menhir, menhir, dan kursi batu (pelinggih), yang merupakan bukti adanya berbagai aktivitas di dalam situs permukiman tersebut. Dolmen dan sarkofagus merupakan bukti adanya kegiatan penguburan, sedangkan menhir, arca menhir dan pelinggih merupakan bukti adanya kegiatan pemujaan.

Mengenai permukiman arkeologi ini, Bruce Trigger (1978) pernah menguraikan faktor-faktor yang berpengaruh pada permukiman tingkat mikro (individual building), tingkat meso (community layouts), dan tingkat makro (zonal pattern). Faktor-faktor yang disebut olehnya sebagai determinants atau faktor-faktor penentu sebagai tersebut di bawah ini

Dari ketiga hal ini situs Pakauman masuk ke dalam permukiman tingkat meso (community layouts) pada masa perundagian. Unsur-unsur yang berpengaruh pada permukiman komunitas jenis ini adalah: mata pencaharian, bahan bangunan, lingkungan, ketrampilan teknologi, spesialisasi produksi, kepercayaan atau religi. Disamping faktor-faktor tersebut di atas, terdapat unsur penunjang lain dalam permukiman antara lain: jaringan jalan, jaringan sungai, sumberdaya alam, lahan pertanian, bangunan pemujaan, dan tempat makam.

\section{a. Mata Pencarian Hidup}

Keterampilan awal yang dimiliki masyarakat megalitik adalah bertani atau bercocok tanam. Penguasaan teknologi pertanian telah dimiliki masyarkat sejak masa bercocok tanam. Telah disebut di bagian depan bahwa seluruh situs di Pakauman merupakan lahan pertanian. Situs merupakan ladang atau tegalan, kecuali di bagian timur yang dekat dengan sungai merupakan sawah basah, yang mungkin dapat pengairan dari Sungai Sampeyan.

Keadaan demikian dapat ditafsirkan bahwa lahan pertanian dan keberadaan sungai diperlukan untuk memenuhi lapangan kerja pertanian bagi masyarakat megalitik di Pakauman. Di samping pertanian, mata pencarian hidup lainnya adalah produksi barang yang berhubungan dengan kemahiran teknik yang telah dimilikinya, seperti: pembuatan gerabah, mengupan alat batu, pengecoran logam, dan kerajinan dari kulit kayu. Bukti adanya kegiatan tersebut dapat kita temukan. Dalam ekskavasi temuan gerabah (baik polos maupun yang berhias) cukup melimpah. Demikian juga temuan fragmen besi/logam dan alat pemukul kulit kayu cukup banyak ditemukan dalam ekskavasi.

Di samping itu pemanfaatan sumberdaya alam juga merupakan mata pencarian hidup yang cukup berarti. Yang dimaksud dengan sumberdaya alam di sini adalah 
keberadaan hutan jati, sono, dan pinus di sekitar situs. Hal ini dapat ditafsirkan bahwa masyarakat telah memerlukan kayu baik untuk kayu bakar, maupun untuk bahan bangunan.

Seperti telah kita ketahui bahwa pada masa perundagian masyarakat telah mengenal berbagai macam ketrampilan, termasuk ketrampilan mengerjakan kayu, disamping telah mengenal pembuatan gerabah dan pengecoran logam. Bahkan páda masa perundagian, terdapat kelompok dalam masyarakat yang berprofesi sebagai pembuat rumah kayu (Soejono, 1984).

\section{b. Kehidupan Religi}

Kehidupan religi telah dimiliki oleh masyarakat megalitik pada masa perundagian. Kehidupan religi yang berpusat pada pemujaan leluhur ini telah ada dan mulai berkembang sejak masa bercocok tanam di Indonesia. Bukti kehidupan religi yang dianut oleh masyarakat megalitik di Pakauman adalah dilakukannya upacara pemujaan dan upacara penguburan.

Masyarakat di Pakauman telah mengenal kehidupan rohani, yang berpusat pada pemujaan roh nenek moyang. Mereka telah melakukan upacara pemujaan. Bukti-bukti adanya perilaku tersebut adalah terdapatnya tinggalan megalitik berupa arca menhir, menhir, dan kursi batu. yang semuanya merupakan media upacara pemujaan leluhur. Di samping itu ekskavasi yang dilakukan di dalam kelompok batu kenong di dekat dengan temuan arca menhir, menghasilkan benda-benda upacara seperti: manikmanik, gelang besi, gerabah, dan temuan emas.

Aktivitas penguburanTerdapat 2 jenis sistem penguburan, pertama menggunakan dolmen dan ke dua menggunakan sarkofagus. Dolmen dan sarkofagus jelas berfungsi sebagai wadah kubur, hal ini sesuai dengan hasil penelitian baik yang dilakukan oleh Willems tahun 1934 maupun oleh Balai Arkeologi Yogyakarta tahun 1985

\section{Penutup}

Dalam bagian terakhir dari kajian yang tidak mendalam ini perlu kiranya dikemukakan beberapa hal. Pertama, berdasarkan pada pengkajian di atas dapat diketahui bahwa situs permukiman atau habitasi adalah merupakan situs tempat manusia bertempat tinggal dan beraktivitas sehari-hari. Sisa aktivitas sehari-hari dapat berupa sisa penggunaan api (arang dan abu), sampah, bekas perlengkapan rumah tangga. Jenis tinggalan dari komunitas lainnya dapat berupa jaringan atau bekas jalan, sisa bangunan rumah, bekas pemujaan, bekas bengkel, dan lokasi penguburan . 
Kedua, pola permukiman adalah cara yang dilakukan oleh manusia di dalam mengatur dirinya di muka bumi dimana dia hidup. Pengertian ini dapat menunjuk tempat tinggal, susunan bangunan dan aspek kehidupan lainnya. Terdapat hubungan antara pola permukiman dengan kebudayaan serta berkait erat dengan geografis atau lingkungan.

Ketiga, sebaran tinggalan arkeologi merupakan petunjuk atau bukti dari okupasi manusia beserta kegiatan-kegiatan yang berkaitan dengan tinggalan tersebut. Hal ini dapat diasumsikan sebagai perwujudan dari gagasan dan tindakan manusia masa lalu. Selain itu, pola sebaran dari bukti-bukti kegiatan manusia tersebut dapat menjadi sumber data bagi pola pikir dan pola tindak masyarakat masa lalu.

Keempat, terdapat kecenderungan bahwa permukiman megalitik di Pakauman, Bondowoso sebagai tempat beraktivitas memilih tempat yang elevasinya relatif rendah, dengan jenis tanaman (vegetasi) yang bervariasi. Lokasi demikian menjamin keleluasaan manusia untuk bergerak lebih mudah dibanding dengan daerah yang miring atau curam. Berdasarkan data empirik tersebut, kiranya dapat ditafsirkan bahwa daerah yang datar dan landai merupakan tempat-tempat yang banyak dimanfaatkan manusia masa lalu untuk penempatan perumahan sebagai pusat kegiatan.

Kelima, bentuk dan pola perkampungan di Pakauman terdiri dari 26 buah rumah kayu atau bambu yang ditopang oleh umpak dari bahan batu dan atapnya dari daun-daun. Rumah-rumahnya berukuran kecil (untuk keluarga kecil) dan bentuknya berjajar di sisi jalan. Secara keseluruhan hubungan antara rumah-rumah tersebut berpola memusat di tengah situs.

Keenam, masyarakatnya telah mengenal kehidupan religi yang berpusat pada pemujaan leluhur. Temuan arca menhir, menhir dan kursi batu, serta temuan bendabenda upacara hasil ekskavasi seperti : manik-manik, gelang besi, gerabah berhias dan temuan fragmen emas, merupakan bukti adanya perilaku pemujaan pada leluhur. Di samping itu cara-cara penguburan (dengan dolmen dan sarkofagus) merupakan bukti adanya kehidupan religi di kalangan masyarakat megalitik di Pakauman.

Ketujuh, mata pencarian hidup masyarakat Pakauman Bondowoso yang utama adalah bercocok tanam dan melaksanakan kegiatan lainnya yang berhubungan dengan ketrampilan teknis yang telah dimiliki seperti antara lain: membuat gerabah, membuat peralatan dari besi, dan membuat kerajinan dari bahan kulit kayu .

Akhirnya, perlu ditandaskan di sini bahwa kajian ini menganut konsep bahwa istilah permukiman atau settlement bukan hanya mencakup situs habitasi, tetapi lebih luas lagi mencakup situs upacara, situs perbengkelan, situs sumber air dan sebagainya yang berkaitan dengan komuniti yang tinggal di situs habitasi. 


\section{KEPUSTAKAAN}

Binford, Lewis R., 1972. An Archaeological Perpective. New York : Seminar Press.

Chang, K.C., 1968. Toward a science of Prehistoric Sosiety. In: Settlement Arehaeology, edited by K.C. Chang. California: National Press Books, pp 1-9

Clark, David L, 1977. Spatial Archaeology, London: Academic Press

Deetz, James., 1968. "Cultural Patterning of Behavior as Reflected by Archaeological Material". In: Settlement Archaeology. Edited by K.C. Chang : Yale University. Palo Alto, California: National Press Books

Hodder, Ian and Clive Orton, 1976. Spatial Analisis in Archaeology, Cambridge: Cambridge University Press

Meggers.B.J. and Clifford Evans Jr., 1956. "The Reconstruction of Settlement Pattern in the South American Tropical Forest", dalam Gordon R. Willy: Prehirtoric settlement Patterns in the New World. Viking Fund Publication in Antropology.

Mundardjito, 1990 "Metode Penelitian Permukiman Arkeologis". Monumen. Karya Persembahan Untuk Prof. Dr. R. Soekmono Lembaran Sastra Seri Penerbitan Ilmiah No. 11 Edisi Khusus Fakultas Sastra Universitas Indonesia.

1993 Pertimbangan Ekologi Dalam Penempatan Situs Masa Hindu-Buda di Daerah Yogyakarta: Kajian Arkeologi-Ruang Skala Makro, Disertasi. Jakarta: Universitas Indonesia (tidak diterbitkan)

Parsons, J.R., 1972. Archaeological Settlement Patterns. In: Annual Review of Anthropology, Vol.I, pp 127-150

Soejono, R.P., 1984. Sejarah Nasional Indonesia.I, Depdikbud. Jakarta : P.N. Balai Pustaka

Thomas, David H., 1979. Archacology. New York: Holt, Rinehart and Winston

Trigger, Bruce G., 1968 "The determinants of Settlement Patterns" In :Settlement Archaeology. Edited by K.C. Chang. Yale University. Palo Alto, California : National Press books 